\title{
DISTRIBUTION OF SURGING GLACIERS IN WESTERN NORTH AMERICA
}

\author{
By Austin Post \\ (U.S. Geological Survey, Tacoma, Washington 98402, U.S.A.)
}

\begin{abstract}
In western North America 204 surging glaciers have been identified by aerial photographic observations. These glaciers exhibit either intense crevassing and rapid ice displacements during surges or distinctive surface features which have resulted from past surges. Distribution of these unusual glaciers is not random throughout the glacierized areas, as they occur only in the Alaska Range, eastern Wrangell Mountains, eastern Chugach Mountains, Icefield Ranges, and the St Elias Mountains near Yakutat and Glacier Bay. No surging glaciers have been identified in the Brooks Range, Kenai Mountains, west and central Chugach Mountains, west and central Wrangell Mountains, Coast Mountains, Rocky Mountains, Cascade Range, Olympic Mountains, or Sierra Nevada. No definite reason for this restricted distribution is apparent. Surging glaciers are found in maritime to continental and temperate to subpolar environments. Practically all physical forms of glaciers are represented. The restricted distribution does not relate to topography, bedrock type, altitude, orientation, or size of glacier. Some surging glaciers are associated with fault-related valleys, but neither recent faulting nor earthquakes have initiated surge activity. Possible causes for the limited distribution of surges are unusual bedrock roughness or permeability in certain areas, anomalously high ground-water temperatures, and/or abnormal geothermal heat flow.
\end{abstract}

RÉsumé. Répartition des glaciers en crue dans l'ouest de l'Amérique du Nord. Dans l'ouest de l'Amérique du Nord, 204 glaciers en crue ont été identifiés par observations photographiques aériennes. Ces glaciers présentent soit des déplacements fortement fissurés et rapides de glace pendant la crue, soit des traits distinctifs de surface qui ont résulté de crue précédente. La répartition de ces glaciers peu communs n'est pas due au hasard dans les régions glaciaires comme cela arrive seulement dans la chaine de l'Alaska, les montagnes Wrangell de l'ouest, les monts Chugach de l'est, les chaines de l'Icefield et les monts St Elias près de Yakutat et le Glacier Bay. Aucun glacier en crue n'a été identifié dans la chaine de Brooks, les monts Kenai, les monts Chugach centre et ouest, les monts Wrangell centre et ouest, les montagnes cotières, les Rocky, la Cascade Range, les monts Olympic ou la Sierra Nevada. Pas de raison bien déterminée n'est apparante pour cette répartition limitée. On trouve les glaciers en crue dans les environments maritimes et continentaux, tempérés et subpolaires. Pratiquement toutes les formes de glaciers sont représentés. La répartition limitée ne s'apparente pas à la topographie, au socle rocheux, à l'altitude, à l'orientation ou à l'épaisseur de glacier. Quelques glaciers en crue sont associés aux vallées apparentées à des failles mais ni une récente faille, ni des tremblements de terre ont amorée une activité en crue. Les causes possibles de la répartition limitée des crues sont: la peu commune inégalité du socle rocheux ou la perméabilité dans certaines régions, les températures irrégulièrement élevées des eaux souterraines et/ou bien l'ecoulement de chaleur géothermique anormal.

Zusammenfassung. Die Verteilung schnell vorstossender Gletscher im westlichen Nordamerika. Mit Hilfe von Luftaufnahmen wurden im westlichen Nordamerika 204 schnell vorstossende Gletscher festgestellt. Diese Gletscher zeigen entweder eine starke Zerspaltung und schnelle Eisbewegungen während eines Ausbruches oder typische Erscheinungen an der Oberfläche, die von früheren Ausbrüchen stammen. Diese ungewöhnlichen Gletscher sind nicht zufällig über die vergletscherten Gebiete verteilt; sie treten vielmehr nur in der Alaska Range, in den östlichen Wrangell und Chugach Mountains, den Icefield Ranges und den St Elias Mountains nahe bei der Yakutat und Glacier Bay auf. Hingegen wurden in der Brooks Range, den Kenai Mountains, den westlichen und zentralen Wrangell und Chugach Mountains, den Coast Mountains, den Rocky Mountains, der Cascade Range, den Olympic Mountains und der Sierra Nevada keine schnell vorstossenden Gletscher gefunden. Für diese beschränkte Verteilung gibt es keine eindeutige Begründung. Schnell vorstossende Gletscher finden sich sowohl in maritimen wie kontinentalen, in gemässigten wie subpolaren Bereichen. Praktisch alle Gletscherformen sind vertreten. Die beschränkte Verteilung hängt auch nicht von der Topographie, dem Untergrund, der Höhenlage, der Exposition oder der Grösse der Gletscher ab. Einige schnell vorstossende Gletscher liegen in Tälern, die Verwerfungen folgen; doch weder junge tektonische Bewegungen noch Erdbeben haben eine Ausbruchstätigkeit eingeleitet. Mögliche Gründe für die beschränkte Verteilung von Ausbrüchen sind: aussergewöhnliche Rauheit oder Durchlässigkeit des Felsuntergrundes in bestimmten Gebieten, ungewöhnlich hohe Grundwasser-Temperaturen und bzw. oder Unregelmässigkeiten im geothermischen Wärmefluss.

\section{How Surging Glaciers are Identified}

A surging glacier is defined as one which periodically ( $15^{-100}+$ years) discharges an ice reservoir by means of a sudden, brief, large-scale ice displacement, which moves ro to roo or more times faster than the glacier's normal flow rate between surges.

Glacier surges are not unique events which might result from exceptional conditions such as earthquakes, avalanches, or local increases in snow accumulation. These movements apparently are due to some remarkable instability which occurs at periodic intervals in certain glaciers (Post, I96o, I966, I967[b]). 
During their active, fast-moving phase, surging glaciers can be recognized by chaotically broken surfaces, sheared margins, and large vertical and horizontal ice displacements. All large and most small surging glaciers in western North America can also be identified when inactive by distinctive surface features which are a result of their periodic changes in flow velocity. Most conspicuous of these features are repeated loops or folds in medial moraines or ice banding, usually formed by the sudden variations in the flow rate of a glacier relative to its tributaries. Longitudinal profiles locally steeper than the profiles of trimlines or lateral moraines may indicate when a surging glacier is approaching critical instability.

All of the larger glaciers known to have surged in western North America clearly display some of the above characteristics. Validity of these indicators is demonstrated by three spectacular, recent surges which were predicted on the basis of such evidence (personal communication from Post to W. A. Wood, 20 December r96o; Post, r 967[b]). These movements took place in the Walsh, Steele, and Chitina Glaciers. No major glacier in the study area which does not display evidence of surge activity has any record of past surges. Thus

Table I. General Distribution of Surging Glaciers in Western North America

\begin{tabular}{|c|c|c|c|}
\hline Mountain range & Subdivision & Basin & $\begin{array}{c}\text { Number of } \\
\text { surging glaciers }\end{array}$ \\
\hline \multirow{19}{*}{ St Elias Mountains } & Fairweather Range & Gulf of Alaska & I \\
\hline & \multirow[t]{2}{*}{ Glacier Bay } & North-western part & 17 \\
\hline & & Johns Hopkins Inlet & 4 \\
\hline & \multirow[t]{2}{*}{ Alsek Ranges } & Klehini River & 2 \\
\hline & & Tatshenshini River & II \\
\hline & Alsek River & West side & 8 \\
\hline & \multirow[t]{2}{*}{ Yakutat } & Russell Fiord and Yakutat Bay & 9 \\
\hline & & Malaspina Glacier & 4 \\
\hline & \multirow[t]{2}{*}{ Chitina River } & Walsh Glacier & $\begin{array}{r}6 \\
6\end{array}$ \\
\hline & & Chitina Glacier & $\begin{array}{r}\text { I } 6 \\
6\end{array}$ \\
\hline & \multirow[t]{9}{*}{ Icefield Ranges } & Kaskawalsh, Slims River & 3 \\
\hline & & Duke River & I \\
\hline & & Donjek River above Steele Creek & 12 \\
\hline & & Steele Creek & 16 \\
\hline & & Cement Creek & 2 \\
\hline & & Wolverine Creek & 1 \\
\hline & & St Clare Creek & 3 \\
\hline & & Count Creek & 2 \\
\hline & & Klutlan Glacier & 12 \\
\hline \multirow[t]{7}{*}{ Wrangell Mountains } & \multirow[t]{3}{*}{ Eastern part } & White River in Alaska & 10 \\
\hline & & Chisana River & 4 \\
\hline & & Nabesna River & $\mathrm{I}$ \\
\hline & \multirow[t]{4}{*}{ Chitina River } & Chitistone River & 3 \\
\hline & & Skolai Creek & 2 \\
\hline & & Barnard Glacier & 2 \\
\hline & & Hawkins Glacier & I \\
\hline \multirow[t]{3}{*}{ Chugach Mountains } & \multirow[t]{3}{*}{ Eastern part } & Bering Glacier & I \\
\hline & & Lowe River & I \\
\hline & & Tasnuna River & I \\
\hline Aleutian Range & Chigmit Mountains & Illiamna Volcano & 2 \\
\hline \multirow[t]{14}{*}{ Alaska Range } & Western part & Hartman River & I \\
\hline & \multirow[t]{4}{*}{ Tordrillo Mountains } & Hayes River & I \\
\hline & & Skwentna River & 4 \\
\hline & & Nagishlamina River & 3 \\
\hline & & Beluga River & 1 \\
\hline & \multirow[t]{3}{*}{ Mt McKinley area } & Kuskokwim River & 1 \\
\hline & & Kantishna River & $\begin{array}{l}7 \\
0\end{array}$ \\
\hline & & $\begin{array}{l}\text { Yentna River } \\
\text { Chulitna River }\end{array}$ & $\begin{array}{l}2 \\
7\end{array}$ \\
\hline & \multirow[t]{4}{*}{ Mt Hayes area } & Yanert Fork & 2 \\
\hline & & Susitna River & 2 \\
\hline & & Maclaren River & I \\
\hline & & Delta River & 2 \\
\hline & \multirow{2}{*}{ Mt Kimball area } & Delta River & 2 \\
\hline & & $\begin{array}{l}\text { Gakona River } \\
\text { Chistochina River }\end{array}$ & $\begin{array}{l}2 \\
2\end{array}$ \\
\hline
\end{tabular}


considerable faith can be placed in the present data on the limited distribution of surging glaciers in western North America. New surges, as they develop in the region, can be predicted to be limited to glaciers located in the areas defined below.

\section{Where Surging Glaciers are Located}

All glaciers which have been observed surging or show some evidence of former surges are shown in Figure I and listed in Table I. Most of these are concentrated in compact groups in the St Elias Mountains and eastern Wrangell Mountains where a wide variety of sizes and forms of surging glaciers have been identified. In the Alaska Range, the majority of these unusual glaciers are located in a long structural valley following the Denali fault (St Amand, 1957). The Hayes Glacier in the Tordrillo Mountains shows unmistakable evidence of surging while several nearby glaciers appear to be subject to these movements. Only a very small number of glaciers which show evidence of surging have been identified in other areas. The large Bering Glacier in the eastern Chugach Mountains surged strongly between 1957 and 1960 , and experienced another weaker pulse in 1965. The Marshall Glacier, 50 km north of Cordova, made a short-lived advance in r96o, and the adjoining Deserted Glacier shows evidence of periodic changes in flow velocity. The Tuxedni and Lateral Glaciers in the Chigmit Mountains display evidence of surges, and a small glacier in the extreme western Alaska Range was advancing anomalously in r954.

In all other glacierized regions in western North America no evidence of surging glaciers has been found. These include extensive glacierized areas of the west and central Chugach Mountains, west and central Wrangell Mountains, and most valleys of the Alaska Range not directly associated with the Denali fault. No evidence of any surging glaciers has been found in the Brooks Range, Aleutian Range west of Illiamna Volcano, Kenai or Coast Mountains in Alaska; Coast, Rocky or Selkirk Mountains in Canada; or the Olympic Mountains, Cascade Range, Rocky Mountains, or Sierra Nevada in the conterminous United States.

The presence of large numbers of surging glaciers in several well-defined areas and the complete absence of them in other areas where many thousands of glaciers are present is too clear to be a coincidental pattern in a random population. Special features must be present in the favored areas which induce the unusual flow characteristics.

\section{Number of Surging Glaciers}

All of the large glaciers and most of the smaller glaciers in western North America have been inspected by aerial reconnaissance and examination of aerial photographs. Of the many thousands of glaciers present 204 have been identified which show evidence of unusual flow.

A number of small glaciers which surge doubtless have not been identified, as small glaciers retain the least evidence of past surge activity. Also, as more information becomes available and allows more precise definition regarding the nature of these unusual movements, some or perhaps many of the smaller glaciers which have made anomalous advances may be omitted from the listing.

A more complete report, including maps and tables listing detailed information on individual surging glaciers, is being compiled.

\section{Recent Activity}

Since the author began aerial inspection in 1960 , thirty-five surges have been observed in western North America. At least twenty-six pre-1960 advances in this area which can be attributed to surges have been reported in the literature. In addition, an examination of aerial photographs taken prior to 1960 by various government agencies and private individuals has located forty-four previously unreported surges which were in progress when the photographs were taken. 


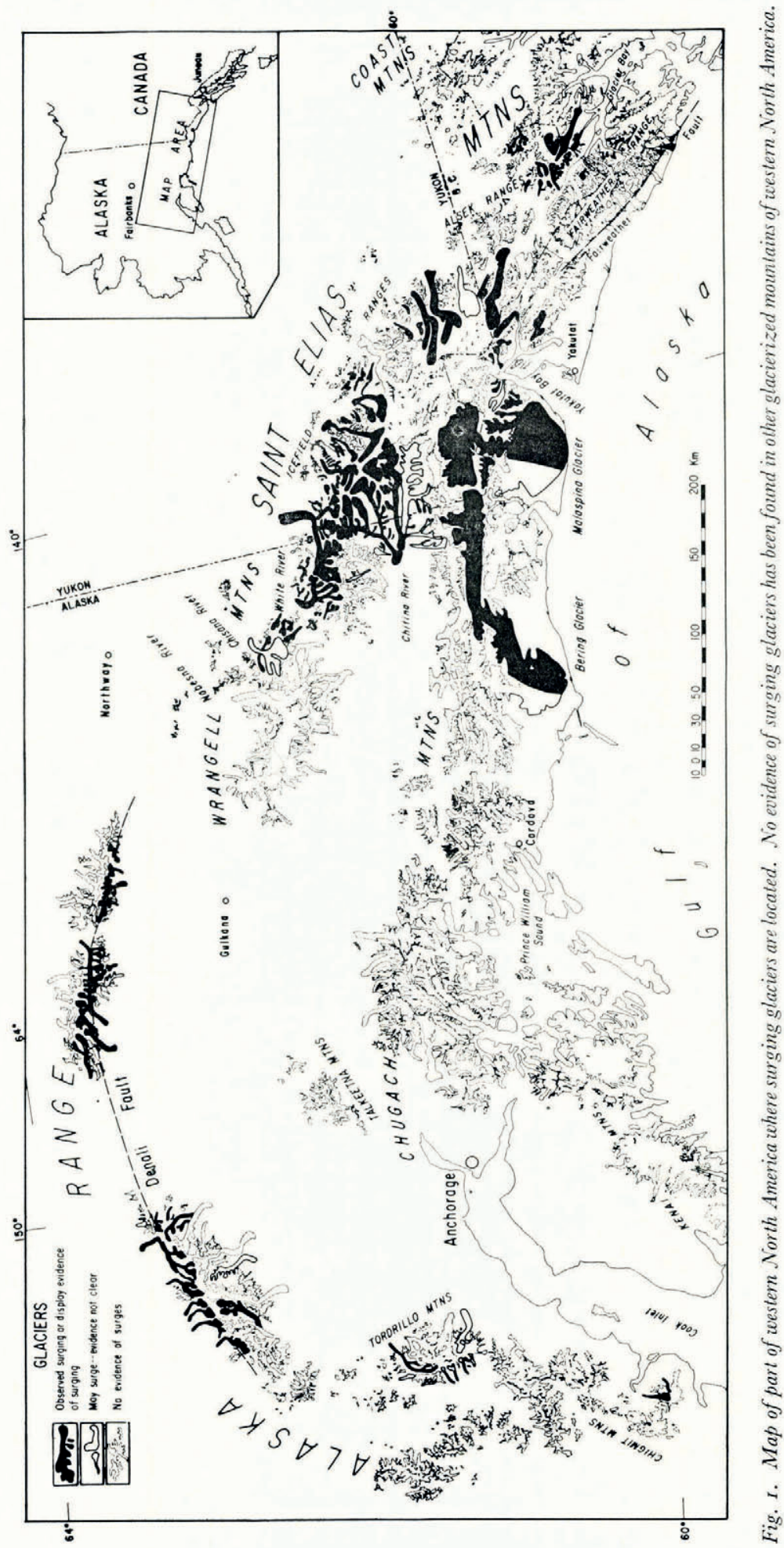


The frequency of the periodic movements of most surging glaciers is unknown. A few of the smaller glaciers have been observed surging more than once, at approximately twenty-year intervals. Major surges of some large glaciers occur at intervals of fifty years or more. The number of glaciers which are active at one time varies greatly; for instance, eighteen glaciers were undergoing surges in I 966 , but most of these had stopped flowing rapidly by August I 967 and only two new surges were observed that year. Although both years were exceptional for the number of active surging glaciers, such year-to-year fluctuations may be coincidental and probably not of climatic significance. An average of five new surges each year has been noted since r 960 . This is consistent with the total number of surging glaciers and the observed periodicity of the surges.

\section{Glacier Size and Shape}

In the search for causes of these unusual movements, common characteristics (other than their distinctive surface features) have been sought. The Bering Glacier, largest $\left(5800 \mathrm{~km}^{2}\right)$ and longest $(200 \mathrm{~km})$ glacier in North America, a small $\left(4 \mathrm{~km}^{2}\right)$ glacier only $\mathrm{I} .7 \mathrm{~km}$ long, and glaciers of various other sizes have now been observed surging, so it is evident that no special size is required. Another possibility might be some special shape, such as basins with very restricted outlets (e.g. Lednik Medvezhiy in the Pamir cited by Dolgushin and others (I 963 )) or glaciers with pronounced subglacial riegels or other obstructions. The presently identified surging glaciers, however, embody nearly every form of glacier found in western North America. The glaciers in Table I include large, branched, low-gradient valley glaciers; simple, small valley glaciers; branches of larger glaciers surging independently; and several small glaciers of various shapes. The common characteristic of surging glaciers is that some part of the glacier acts as an ice reservoir which fills and discharges periodically.

The majority of the surging valley glaciers have moderate, even gradients which reflect uncomplicated bedrock configurations. On the other hand, many smaller surging glaciers discharge from hanging valleys or flow down steep slopes. It is apparent that no particular shape of glacier is required to induce surges.

\section{Earthouakes and Earthouake-induged Avalanching}

No direct connection has been found either in time or space between glacier surges and earthquakes recorded since 1900 (Post, 1965). The earthquake-advance theory of Tarr and Martin (1914, p. I62-97) is not supported by recent observations. Even very large rock-slide avalanches on glaciers resulting from the 1964 Alaska earthquake have failed to induce surges (Post, I967[a]).

\section{Climatic Environments}

Surging glaciers are not confined to any particular climatic zone in north-western North America. Figure 2 shows the approximate annual precipitation for various climatic regions in south-central Alaska and adjacent Canada. Many surging glaciers are found in the humid, mild, maritime environment near Yakutat on the Pacific coast (Fig. 3). However, the majority are found in the interior where sub-maritime to continental conditions prevail (Fig. 4).

Great extremes in the activity index (Meier and Post, r962) or the exchange (sum of accumulation plus ablation) of surging glaciers in these two dissimilar environments are certain. The high-altitude interior glaciers receive light snow accumulation and ablation is moderate. In the interior Icefield Ranges, at the Hubbard-Kaskawalsh divide (altitude $2640 \mathrm{~m}$ ), annual accumulation for 1965 was slightly over I $300 \mathrm{~mm}$ water equivalent (personal communication from Melvin Marcus, 1968). On the low-altitude icefields near the coast accumulation is very heavy; for example, $4772 \mathrm{~mm}$ of precipitation occurred the same year at Yakutat. Snow and ice ablation at low altitudes is correspondingly large. It thus 


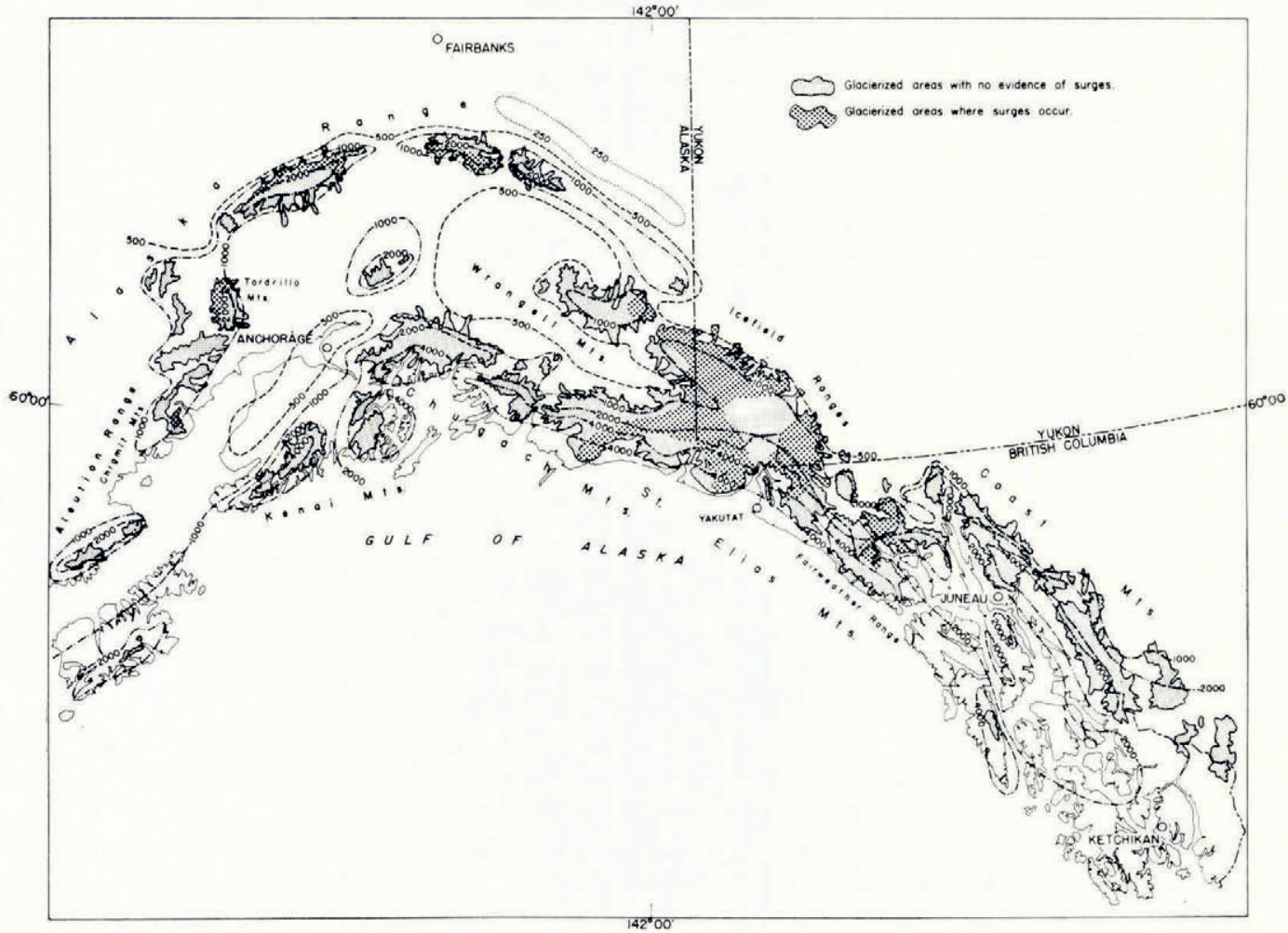

Fig. 2. Map showing precipitation in parts of Alaska and Canada. Because direct measurements of precipitation in most mountainous areas are not available, many of the values shown here have been derived by comparing stream flow with precipitation records of lowland stations in selected river basins. Values are in millimeters of water. Note the narrow strip of very heavy precipitation $(4000-5000 \mathrm{~mm}$ ) along the coast of the Gulf of Alaska. Precipitation drops to only about one third of coastal values in a traverse across the St Elias Mountains north of Yakutat (personal communication from Melvin Marcus, 1968). Values one half to one third of the coastal precipitation are probably typical of most inland glacierized areas.

seems unlikely that the activity index or exchange of these glaciers can have any pervasive effect.

The firn line on the coast in the Gulf of Alaska is at about I $000 \mathrm{~m}$; these low-altitude glaciers are presumably temperate (Meier and Post, 1962). The firn-line altitude in the interior ranges is as high as $2500 \mathrm{~m}$; presumably many of the surging glaciers in that region are sub-polar. On "Fox" glacier at altitude $2250 \mathrm{~m}$ on the interior side of the Icefield Ranges, ice temperatures of $-3.2^{\circ} \mathrm{C}$ near the surface and $-6.4^{\circ} \mathrm{C}$ at $20 \mathrm{~m}$ depth have been reported (personal communication from G. P. Rigsby, I968). Although other data on subglacial and englacial temperatures are lacking, surging glaciers in western North America apparently include both sub-polar and temperate types.

\section{TOPOGRAPHY}

All glaciers in western North America are located in rugged, mountainous terrain. The physical relief where surging glaciers are located does not differ in any conspicuous way from many regions where surging glaciers are not found. No particular orientation is favored (Fig. I).

\section{Rock Types}

The nature of the rock type varies greatly from region to region and little information is available where most surging glaciers are located. A generalized geologic map of the eastcentral part of the Alaska Range (Fig. 5) demonstrates that here surging glaciers are not 


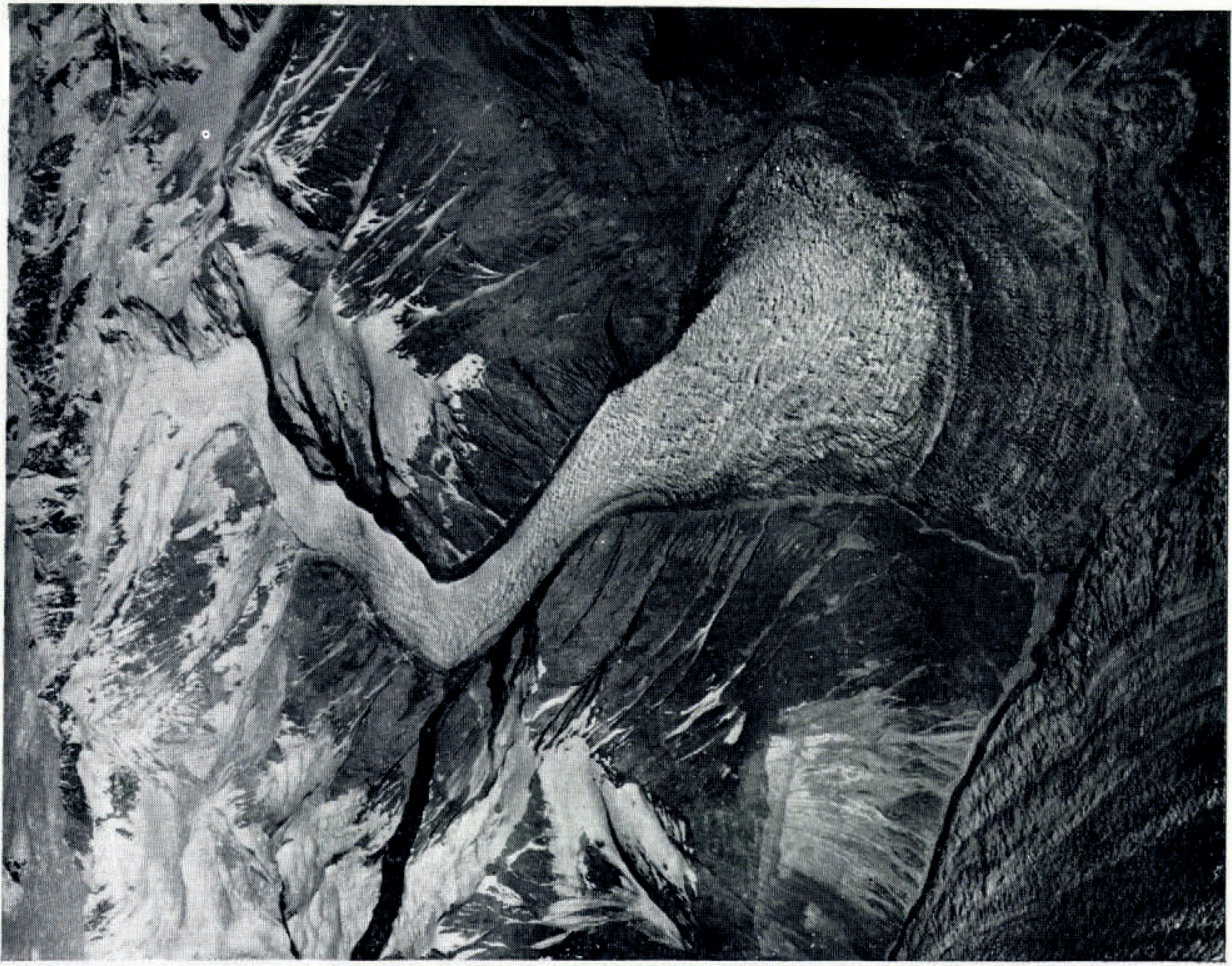

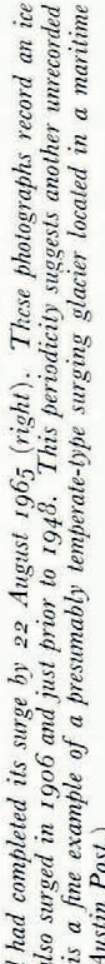

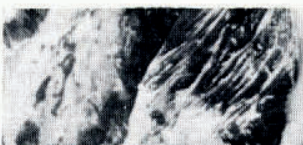

ifte

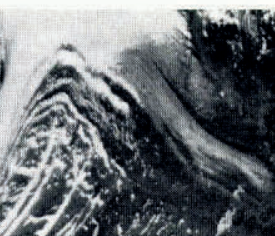

Tinge

ฮ.

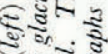

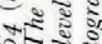

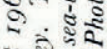

)

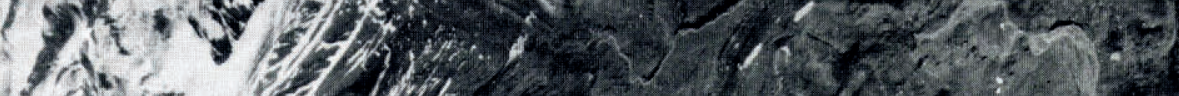

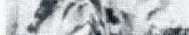

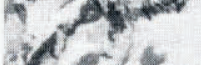

Co

rint

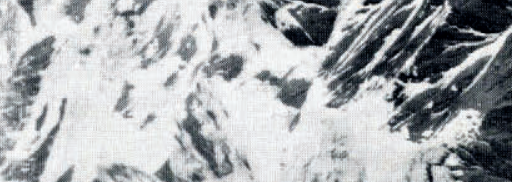

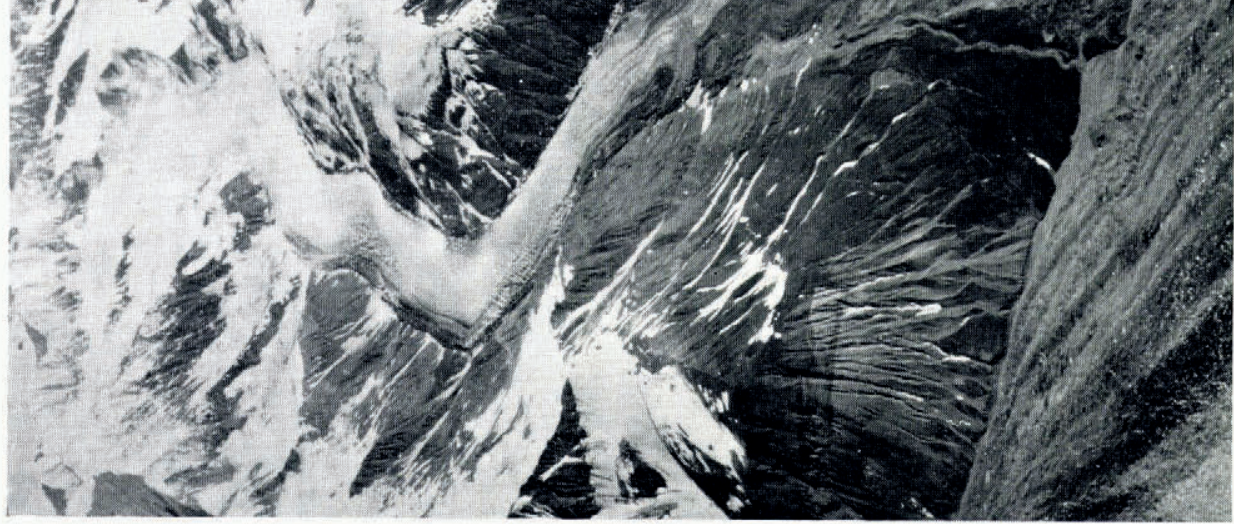

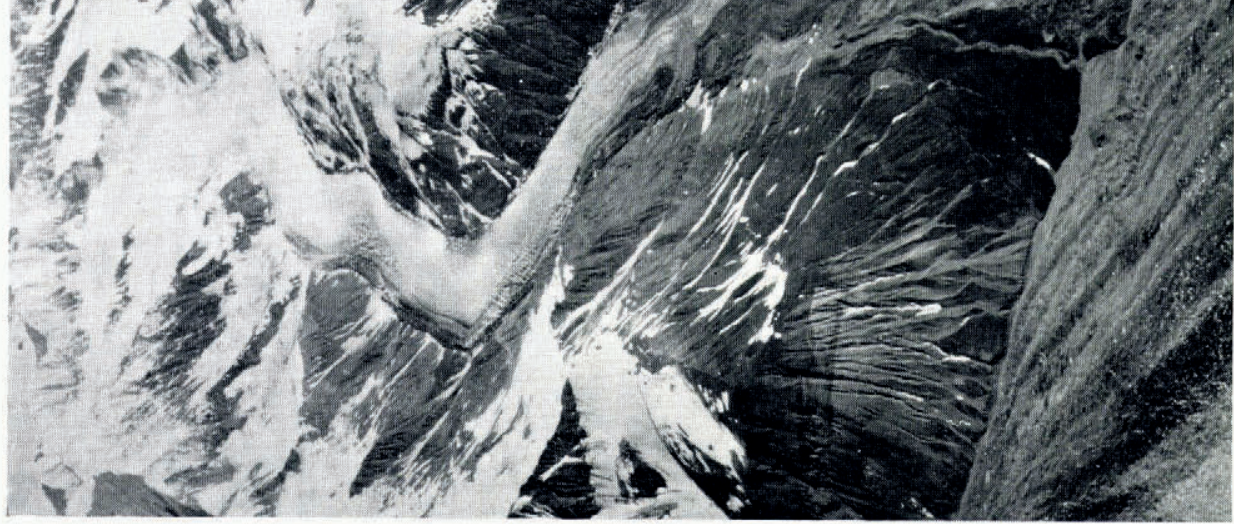

政 


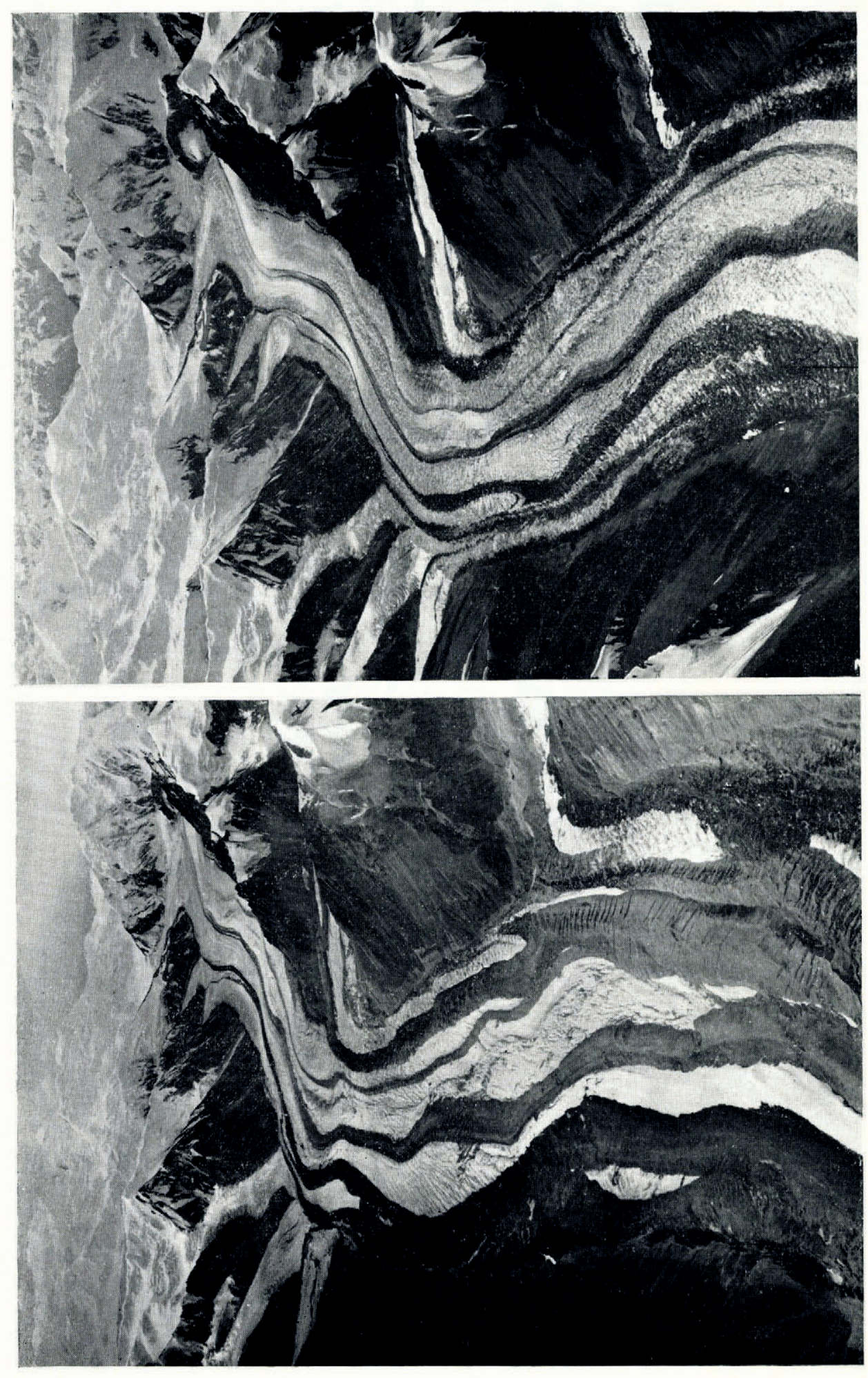

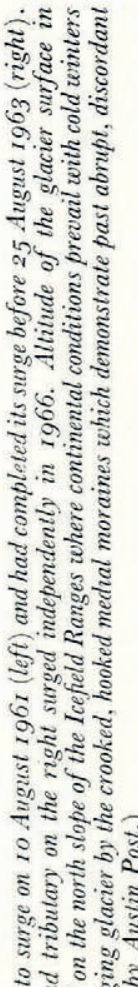

का के की

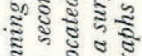

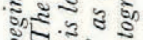

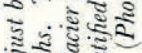

उ की क्षै

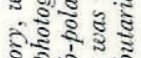

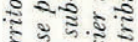

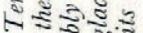

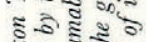

然莡

०ิ.

范

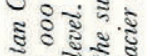

₹ + ग क

ใ.

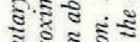

총유

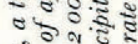

:

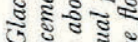

․․ㄴ

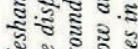

$<$.

भंषें है

宅 


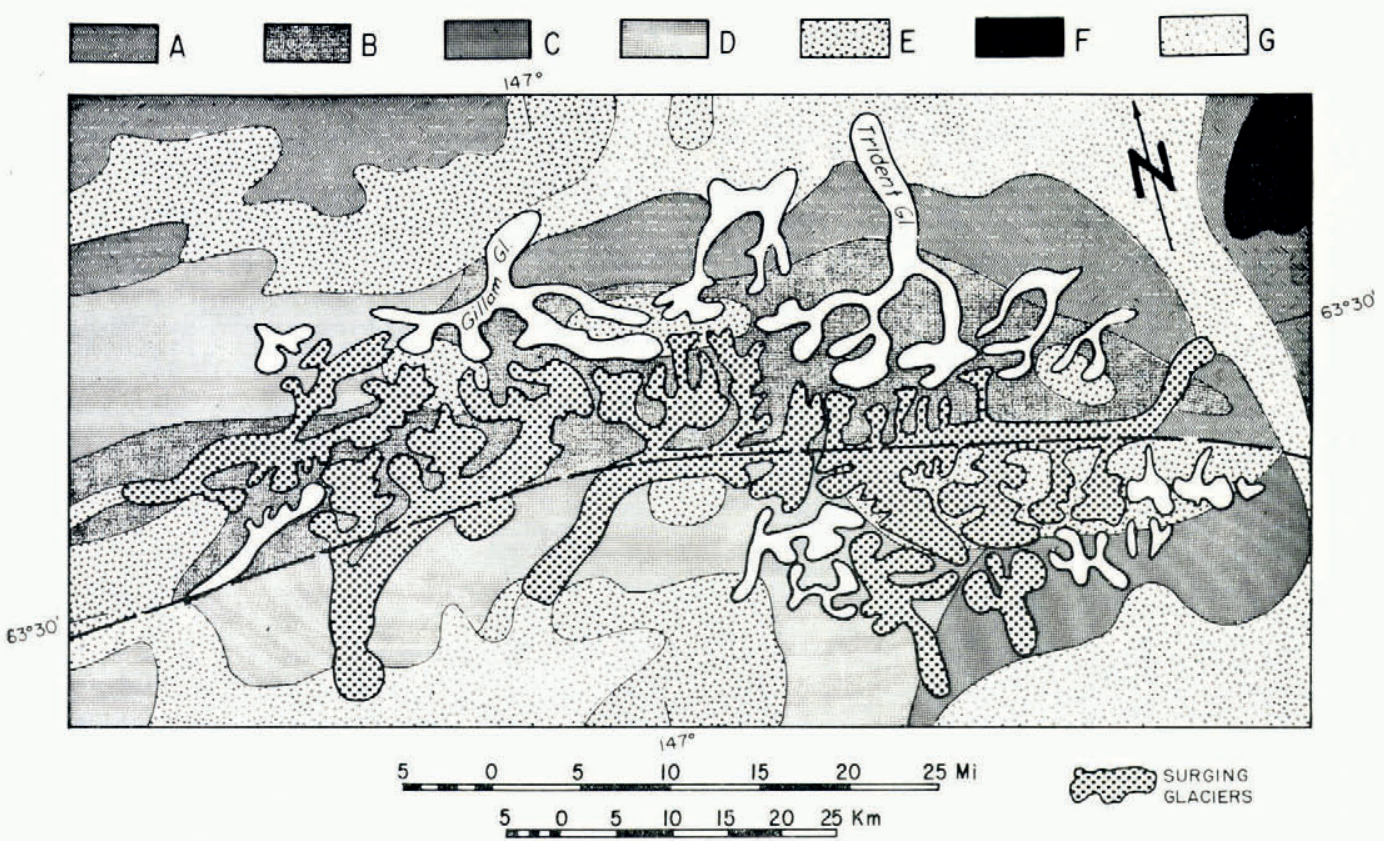

Fig. 5. Surging glaciers in the eastern Alaska Range showing their relationship to the Denali fault (heavy dashed line) and various rock types, as follows: A, lower pre-Cambrian metamorphic rocks; $B$, Silurian-Devonian marine limestone; $C$, Permian limestone and marine clastic rocks, D. Cretaceous (lower part), Furassic, and Triassic marine and non-marine sedimentary rocks; $E$, Cretaceous and Jurassic intrusive rocks; $F$, Tertiary marine and non-marine sedimentary rocks; $G$, Quaternary sedimentary deposits (after Dutro and Payne*; Moffit, 1955).

confined to any particular rock type. Most other surging glaciers are located in areas where detailed geological mapping is incomplete. In some localities surging glaciers occur where the bedrock is predominantly sedimentary, such as the Bering Glacier. Volcanic rocks underlie some of the glaciers north of the Icefield Ranges in the vicinity of Steele Glacier. Some surging glaciers, such as the Peters and Muldrow, occur near large plutonic, igneous bodies such as Mount McKinley; small plutons doubtless occupy parts of most of the large glacier basins. Metamorphic rocks underlie some surging glaciers in the Icefield Ranges and the Alaska Range. In most regions, such as the Alaska Range and St Elias Mountains north of Yakutat, several rock types are present without surging glaciers being limited to any particular type or combination of types. However, no surging glaciers are located in the predominantly granitic Coast Mountains or the little-altered sedimentary formations of the Rocky Mountains.

The limited distribution of surging glaciers is evidently not related to the predominance of any single type of bedrock. But much more detailed mapping of bedrock under surging and non-surging glaciers is necessary before the relationship of rock types to surges is understood.

\section{Bedrock Roughness and Permeability}

The degree and nature of the roughness of bedrock under glaciers may be a critical factor in determining the rate at which a glacier slips on its bed (Weertman, r964). It seems somewhat doubtful that some unique surface roughness is the cause for the limited distribution of surging glaciers in western North America. Large numbers of glaciers in some areas surge, regardless of size and shape, while none do in other areas where bedrock and topography are

* Dutro, J. T., jr., and Payne, T. G. 1954. Geologic map of Alaska. U.S. Geological Survey. Map MR 8024. I : 2500000 . 
apparently quite similar. Detailed studies are needed to determine the nature and roughness of bedrock before more complete answers to this question are possible.

The permeability of bedrock or subglacial unconsolidated deposits could also be a factor which might induce glacier surges if a film of water under the glacier is associated with these movements. The nature of the bedrock, as indicated above, has not been studied in sufficient detail to permit analysis of this question. Most surging glaciers appear to be located in areas where the bedrock has been subject to severe deformation. The association of surging glaciers to some fault-related valleys where the bedrock is probably badly shattered and presumably more permeable than in most other areas might suggest that high bedrock permeability is necessary for surges. The lack of surging glaciers in the granitic and presumably low permeability Coast Mountains might also support this suggestion. However, there are many areas of high permeability sedimentary formations or highly deformed rock where the glaciers do not surge. As with bedrock roughness, detailed research is necessary before this question can be answered with certainty.

\section{Possible Subglacial Temperature Anomalies}

Subglacial temperature anomalies causing glaciers to surge in certain localities may be a possible explanation. Unfortunately no subglacial temperatures have been measured under surging glaciers up to the present time. Heat transfer by surface heat balance, water convection, and ice flow convection presumably would be very nearly the same for contiguous glaciers in various environments whether of the surging or nonsurging type. Friction within the ice and friction on the bed are normally small quantities although these, particularly bed friction, may become important sources of heat once the ice flow has gained considerable velocity during surges. The two sources of heat remaining which could foreseeably produce large-scale anomalous temperatures under a glacier are ground-water convection and the conduction of heat through the bedrock itself. High heat flow by these means could be due to incipient volcanism, friction along active faults, or recently emplaced plutons at depth.

\section{Volcanoes}

Although few heat-flow data are available near volcanic peaks of the North-West it seems reasonable to assume that positive anomalies in heat flow may exist at least near those that have experienced recent eruptions. Anomalies in some ground-water temperatures are indicated by the presence of hot springs near some of the inactive cones.

Examination of the glaciers of the volcanic peaks of western North America has revealed only two glaciers that show evidence of past surges. The most positive of these is the Tuxedni Glacier on Illiamna Volcano, Chigmit Mountains (Fig. I). It is unique both in its length $(24 \mathrm{~km})$ and low gradient $\left(5^{0} \mathrm{~m}\right.$ per $\left.\mathrm{km}\right)$ for glaciers of the volcanic peaks. The absence of more surging glaciers on these peaks might be due largely to their physical form. Typically, glaciers on volcanoes are located on steep, unconfined, diverging slopes that are least favorable to the formation of the ice reservoirs associated with surges.

The absence of surging glaciers on most volcanoes in western North America does not preclude the possibility that abnormally high geothermal heat may induce these movements. Periodic surges of several of the Vatnajökull outlet glaciers in Iceland (Thorarinsson, 1964) that are located on active volcanic terrain suggests such effects.

\section{FAULTS}

Abnormally high heat flow and anomalies in ground-water temperatures along faults was suggested as a cause of surges by Zane Spiegel (personal communication, 1960). A few, but by no means all, structural valleys which follow major faults contain surging glaciers. Typically, nearby valleys contain very similar glaciers which show no evidence of surging. The most notable example of this relationship is the long, narrow structural depression following 
sections of the Denali fault in the Alaska Range (Fig. I). Practically every glacier occupying parts of this valley shows evidence of periodic, rapid movements, and four-the Muldrow, Susitna, Black Rapids, and Gakona-have made spectacular surges in recent years. The striking relationship of surging glaciers to this fault and the absence of surging glaciers in most other nearby valleys indicates some direct association with this feature.

St Amand (1957) has suggested that surges may be due to fault displacements. No recent displacements have taken place along the Denali fault which might be directly related to glacier surges. Displacements up to $6 \mathrm{~m}$ along the Fairweather fault accompanied the severe $195^{8}$ earthquake (Tocher and Miller, 1959). The La Perouse Glacier crosses this fault east of Crillon Lake. Rapid, short-lived advances of its terminus into tidewater have occurred from time to time. It is not known whether the most recent advance, noted in 1966 , may be related to fault displacements which took place during the $195^{8}$ earthquake. Due to the long interval separating the earthquake and the advance, a direct connection appears unlikely. Furthermore, the Fairweather fault trench is almost continuously occupied by glaciers from Crillon Lake to and beyond the Alsek River, a distance of more than $150 \mathrm{~km}$ (Fig. I). Fault displacement during the 1958 earthquake under the large Grand Plateau Glacier was dramatically demonstrated by a fracture visible in the glacier surface that followed the fault trace (personal communication from George Plafker, ig68). Not one of these glaciers surged as a result of the $195^{8}$ earth movements and there is no evidence indicating that any of these glaciers have surged in the past. Continuing strain in the vicinity of these active faults might have some minor effect on subglacial drainage, but little is known about strain patterns in these mountainous regions and it is difficult to see why strain would cause many surges in some areas (e.g. near the Denali fault), but produce no surges in other areas of presumably greater deformation (e.g. Fairweather fault, western Chugach Range). It thus appears fairly certain the glacier surges are not related to earth displacements along faults. The most likely association between surging glaciers and fault valleys appears to be either unusual bedrock roughness or permeability found along certain faults or anomalous heat flow in their vicinity.

As the distribution of surging glaciers in Figure I indicates, surges are by no means limited to certain fault-associated valleys. Particularly in the St Elias Mountains the general regions where surging glaciers are located are quite extensive. Clearly they cannot be directly related to any one fault and the large percentage of surging glaciers in these regions makes it appear that the condition favoring surges is almost universal within the affected regions. If anomalous heat flow is the cause it must be present over broad areas.

\section{Conclusions}

The limited distribution of surging glaciers in western North America indicates that special conditions found only in certain geographical areas favor these unusual movements. Their cause cannot be limited to internal properties of glacier ice alone but must include external forces not universally present.

Several possible unique conditions have been eliminated. No special size or shape of glacier is necessary. No special mean air temperature, precipitation, altitude, or activity index is favored. No relationship to earthquakes either in time or space is evident. No particular rock type is indicated. Distinctive differences in permeability or surface roughness of bedrock in areas where surging glaciers are located do not appear likely but require further study.

Many surging glaciers are found in the Denali fault valley, but some other fault valleys do not contain surging glaciers even though recent earth movements may have taken place. Many surging glaciers are found scattered or in groups in other fairly well defined areas without any clear relationship to faults.

The two causes that appear most likely to explain the limited distribution of surging glaciers in western North America are (a) anomalous subglacial temperatures, and (b) unusual bedrock roughness or permeability. Perhaps a special combination of these conditions may be necessary to produce the unusual conditions at the bed of a glacier which cause surges. 


\section{Acknowledgements}

Aerial glacier observation and photography from i96o to 1964 were sponsored by the U.S. National Science Foundation and administered by the University of Washington. The U.S. Geological Survey has continued these annual observations. Lawrence Mayo collaborated on the precipitation map.

MS. received 30 August I968

\section{REFERENCES}

Dolgushin, L. D., and others. 1963. Nedavneye nastupleniye Lednika Medvezh'yego [The recent advance of the Medvezhiy glacier], [by] L. D. Dolgushin, S. A. Yevteyev, A. N. Krenke, K. G. Rototayev [and] N. M. Svatkov. Priroda, 1963, No. I 1, p. 85-92. [English translation: Canada. Defence Research Board. Report No. T 409 R, translated by E. R. Hope, 1964.]

Meier, M. F., and Post, A. S. 1962. Recent variations in mass net budgets of glaciers in western North America. Union Géodésique el Géophysique Internationale. Association Internationale d'Hydrologie Scientifique. Commission des Neiges et Glaces. Colloque d'Obergurgl, $10-9-18-9$ 1962, p. 63-77.

Moffit, F. H. 1955. Geology of the eastern part of the Alaska Range and adjacent areas. U.S. Geological Survey. Bulletin 989 .

Post, A. S. 196o. The exceptional advances of the Muldrow, Black Rapids, and Susitna Glaciers. Fournal of Geophysical Research, Vol. 65, No. 11, p. 3703-12.

Post, A. S. 1965. Alaskan glaciers: recent observations in respect to the earthquake-advance theory. Science, Vol. 148 , No. 3668 , p. $366-68$.

Post, A. S. I966. The recent surge of Walsh Glacier, Yukon and Alaska. Journal of Glaciology, Vol. 6, No. 45, p. $375^{-8 \mathrm{I}}$.

Post, A. S. I967[a]. Effects of the March 1964 Alaska earthquake on glaciers. U.S. Geological Survey. Professional Paper 544-D.

Post, A. S. I967[b]. Walsh Glacier surge, I966 observations. Journal of Glaciology, Vol. 6, No. 47, p. $763-65$.

St Amand, P. 1957. Geological and geophysical synthesis of the tectonics of British Columbia, the Yukon Territory, and Alaska. Bulletin of the Geological Society of America, Vol. 68, No. 10, p. 1343-70.

Tarr, R. S., and Martin, L. 1914. Alaskan glacier studies of the National Geographic Society in the Yakutat Bay, Prince William Sound and lower Copper River regions. Washington, D.C., National Geographic Society.

Thorarinsson, S. 1964. Sudden advance of the Vatnajökull outlet glaciers 1930-1964. Jökull, [Vol.] 3, Ár I4, p. $76-89$.

Tocher, D., and Miller, D. J. 1959. Field observations on effects of Alaska earthquake io July 1958. Science, Vol. 129, No. 3346, p. 394-95.

Weertman, J. 1964. The theory of glacier sliding. Journal of Glaciology, Vol. 5, No. 39, p. $287-303$. 